\title{
Description of Lacon mertliki sp. nov. (Coleoptera: Elateridae: Agrypninae) from the Hyrcanian forest ecoregion, with a key to the Lacon species of Iran
}

\author{
Robin KUNDRATA ${ }^{1, *}$, Tamás NÉMETH ${ }^{2} \&$ Andrea JARZABEK-MÜLLER ${ }^{3}$ \\ ${ }^{1}$ Department of Zoology, Faculty of Science, Palacky University, 17. listopadu 50, \\ 77146 Olomouc, Czech Republic. \\ ${ }^{2}$ Hungarian Natural History Museum, Department of Zoology, Baross utca 13, \\ H-1088 Budapest, Hungary. \\ ${ }^{3}$ Anton-Hilz-Straße 42, D-94566 Riedlhütte, Germany. \\ *Corresponding author: robin.kundrata@upol.cz \\ 2Email: nemeth.tamas@nhmus.hu \\ 33Email: andrea_jarzabek@yahoo.de \\ ${ }^{1}$ urn:1sid:zoobank.org:author:98C7998C-7752-47A5-91FE-9A05D306FB92 \\ ${ }^{2}$ urn:1sid:zoobank.org:author:9A6B1405-6858-435C-96A3-75FDEF760DC2 \\ ${ }^{3}$ urn:1sid:zoobank.org:author:EAC3DC5F-0C38-4208-93E9-0AC4D1BAD655
}

\begin{abstract}
In this study we describe a new species of the click-beetle genus Lacon Laporte, 1838 from the relict Hyrcanian forest in northern Iran. Lacon mertliki sp. nov. is morphologically similar to L. lepidopterus (Panzer, 1801) but differs from the latter in the body coloration and pubescence, the shape of pronotum and scutellar shield, and male and female genitalia. We provide brief data on its ecology as well as an identification key to all Lacon species in Iran. Additionally, we synonymize Lacon nadaii Platia \& Németh, 2011 with Lacon unicolor (Candèze, 1874).
\end{abstract}

Keywords. Distribution, diversity, Elateroidea, Palearctic region, systematics.

Kundrata R., Németh T. \& Jarzabek-Müller A. 2019. Description of Lacon mertliki sp. nov. (Coleoptera: Elateridae: Agrypninae) from the Hyrcanian forest ecoregion, with a key to the Lacon species of Iran. European Journal of Taxonomy 535: 1-13. https://doi.org/10.5852/ejt.2019.535

\section{Introduction}

Lacon Laporte, 1838 is a morphologically rather diverse and geographically widespread genus in the click-beetle subfamily Agrypninae (e.g., Johnson 2002; Cate 2007; Girard 2017; Kundrata et al. 2018). More than 50 species are known from the Palearctic region, but there are probably more to be added, because Lacon in various part of the region still lacks proper taxonomic revisions (Cate 2007; Mertlik \& Németh 2014; Prosvirov 2016a, 2016b, 2017). Seven species of Lacon are reported from Iran: L. funebris (Solsky, 1881), L. lepidopterus (Panzer, 1801), L. mekrani (Candèze, 1889), L. modestus (Boisduval, 1835), L. nadaii Platia \& Németh, 2011, L. punctatus (Herbst, 1779) and 
L. unicolor (Candèze, 1874) (Mardjanyan \& Barimani Varandi 2014; Platia \& Ghahari 2016). Based on the examination of material deposited in the Naturhistorisches Museum in Vienna, Austria as well as the freshly collected specimens from expeditions to the Hyrcanian forest ecoregion of Iran by Jörg Müller and Frank Lange (2016) and research by Farzaneh Kazerani (2018), we found a new species of Lacon morphologically similar to L. lepidopterus but different in various aspects. The aim of this study is to formally describe and figure the above mentioned species, and compare it with other Lacon species in the region.

\title{
Material and methods
}

The genitalia were dissected after a short treatment in hot $10 \% \mathrm{KOH}$. Main diagnostic characters were photographed using a Nikon D5200 camera attached to a Mitutoyo M Plan Apo 5X microscope lens. The measurements were taken with an eyepiece graticule. Body length was measured from the anterior margin of head to the apex of the elytra, body width at about middle of elytra, pronotal length at midline, pronotal width at middle, scutellar shield length at midline, and scutellar shield width at middle. The definition and limits of Lacon follow Hayek (1973) and Cate (2007). Morphological terminology generally follows Prosvirov (2016a, 2016b), and antennal terminology follows Faucheux \& Kundrata (2017). The type and identified non-type specimens of Lacon species from the Levant, Asia Minor, the Middle East and Central Asia used for comparison with the new species described here were studied in the following collections.

\author{
Repositories \\ $\mathrm{BMNH}=$ Natural History Museum, London, United Kingdom \\ $\mathrm{HNHM}=$ Natural History Museum, Budapest, Hungary \\ MNHN $=$ Muséum national d'Histoire naturelle, Paris, France \\ NHMW $=$ Naturhistorisches Museum, Vienna, Austria \\ NMPC $=$ Národní muzeum Praha, Czech Republic \\ PCAJM = private collection of Andrea Jarzabek-Müller, Riedlhütte, Germany \\ PCFL $=$ private collection of Frank Lange, Niedernhausen, Germany \\ PCRK = private collection of Robin Kundrata, Olomouc, Czech Republic \\ $\mathrm{PCJM}=$ private collection of Josef Mertlík, Opatovice nad Labem, Czech Republic \\ SDEI $=$ Senckenberg Deutsches Entomologisches Institut, Müncheberg, Germany
}

Label data are cited verbatim, with different labels separated by a double slash "//".

\section{Results}

\author{
Class Hexapoda Blainville, 1816 \\ Order Coleoptera Linnaeus, 1758 \\ Suborder Polyphaga Emery, 1886 \\ Series Elateriformia Crowson, 1960 \\ Superfamily Elateroidea Leach, 1815 \\ Family Elateridae Leach, 1815 \\ Subfamily Agrypninae Candèze, 1857
}

Genus Lacon Laporte, 1838

Lacon Laporte, 1838: 11. Type species: Elater atomarius Fabricius, 1798, by subsequent designation (Hyslop 1921: 652). For a list of synonyms and other details see Hayek (1973: 52) and Cate (2007: 100). 


\title{
Description of a new species
}

\author{
Lacon mertliki sp. nov. \\ urn:1sid:zoobank.org:act:168C9BE1-BC15-411C-9614-15303E8CB8C4 \\ Figs $1 \mathrm{~A}-\mathrm{D}, 2 \mathrm{~A}-\mathrm{B}, \mathrm{E}-\mathrm{H}, \mathrm{K}, 3 \mathrm{~B}-\mathrm{G}$
}

\section{Diagnosis}

Lacon mertliki sp. nov. is morphologically similar to L. lepidopterus. Both species share the body shape and size, type of pubescence, short antennae, pronotal disc with tubercles and impressions, and the similar shape of genitalia. They differ in the coloration of body (reddish brown to dark brown in L. lepidopterus, black in L. mertliki sp. nov.) and pubescence (usually uniformly golden and black in L. lepidopterus, black and silver/yellowish with some white setae in L. mertliki sp. nov.; Figs $1 \mathrm{~A}-\mathrm{H}$, 4A), the shape of pronotum (posterior angles more divergent in L. lepidopterus, especially in male; Fig. 2A-D), scutellar shield (relatively narrower in L. lepidopterus; Fig. 2G-J), male parameral apical lobes (Fig. 3A-B) and the spines of the large sclerite of bursa copulatrix (Fig. 3G here and fig. 11 in Prosvirov 2016b). Lacon punctatus shares with L. mertliki sp. nov. the body shape and size, black coloration and scale-like body pubescence, but it differs in black and white setae, slightly longer antennae, the shape of pronotal disc (longer than wide, usually widest at posterior angles, and with posterior angles more divergent in L. punctatus; slightly wider than long, widest at half, and with posterior angles less divergent in L. mertliki sp. nov.), aedeagus (apical lobe of paramere more subparallel-sided and with more rounded apex in L. punctatus), and the large sclerite of bursa copulatrix (thinner sclerite in L. punctatus). Remaining Lacon species from Iran have thinner, hair-like body pubescence, lack distinct tubercles and impressions on pronotal disc, and all also differ in the male and female genitalia. Additionally, Lacon modestus and L. mekrani differ from L. mertliki sp. nov. mainly in having a shiny, lighter body with sparser punctation, distinct sublateral carina on pronotal posterior angles, and prominent oblique keels on elytra near scutellar shield covered with thin setae, L. unicolor and $L$. nadaii in having more elongate pronotum, distinctly longer than wide, and L. funebris in much sparser and smaller pronotal punctation.

\section{Etymology}

The species name is a patronym in honor of Josef Mertlík (Opatovice nad Labem, Czech Republic).

\section{Type material}

Holotype

IRAN • đ̊; "Pers. Kopet-Dagh., Siaret [= Iran, Golestan: Ziarat], 1160 m., 5.99. Col. Hauser"; NHMW.

\section{Paratypes}

IRAN • 2 우; same data as for holotype; NHMW • 1 q; "Persia, Astrabad. [= Iran, Golestan: Gorgan], 5.99. Coll. Hauser"; NHMW • 1 o; "Iran, Golestan Prov., near Tangrah, 494 m a.s.1., $37.39472^{\circ}$ N, 55.79771 E, 5.X.2016. leg. J. Müller”; PCAJM • 1 क. "Iran, Mazandaran Prov., S Galugah, 1200 m a.s.l., in brown rotting log, 6.X.2016. leg. F. Lange"; PCFL • 1 क; "Iran, Gilan Prov., Shafarood forest, 1138 m a.s.1., $36.652^{\circ}$ N, $53.841^{\circ}$ E, Natural forest, window trap, month July 2018, leg. F. Kazerani”; PCAJM.

\section{Description}

Male holotype (Figs 1A-C, 2A, E, G, K, 3B-C)

Size. $15.3 \mathrm{~mm}$ long, $4.8 \mathrm{~mm}$ wide.

BODY AND COLOR. Elongate, very slightly convex, matt, blackish; articulations of legs and tarsi reddish brown to dark brown. Body densely covered with combination of black (majority) and silver/yellowish 

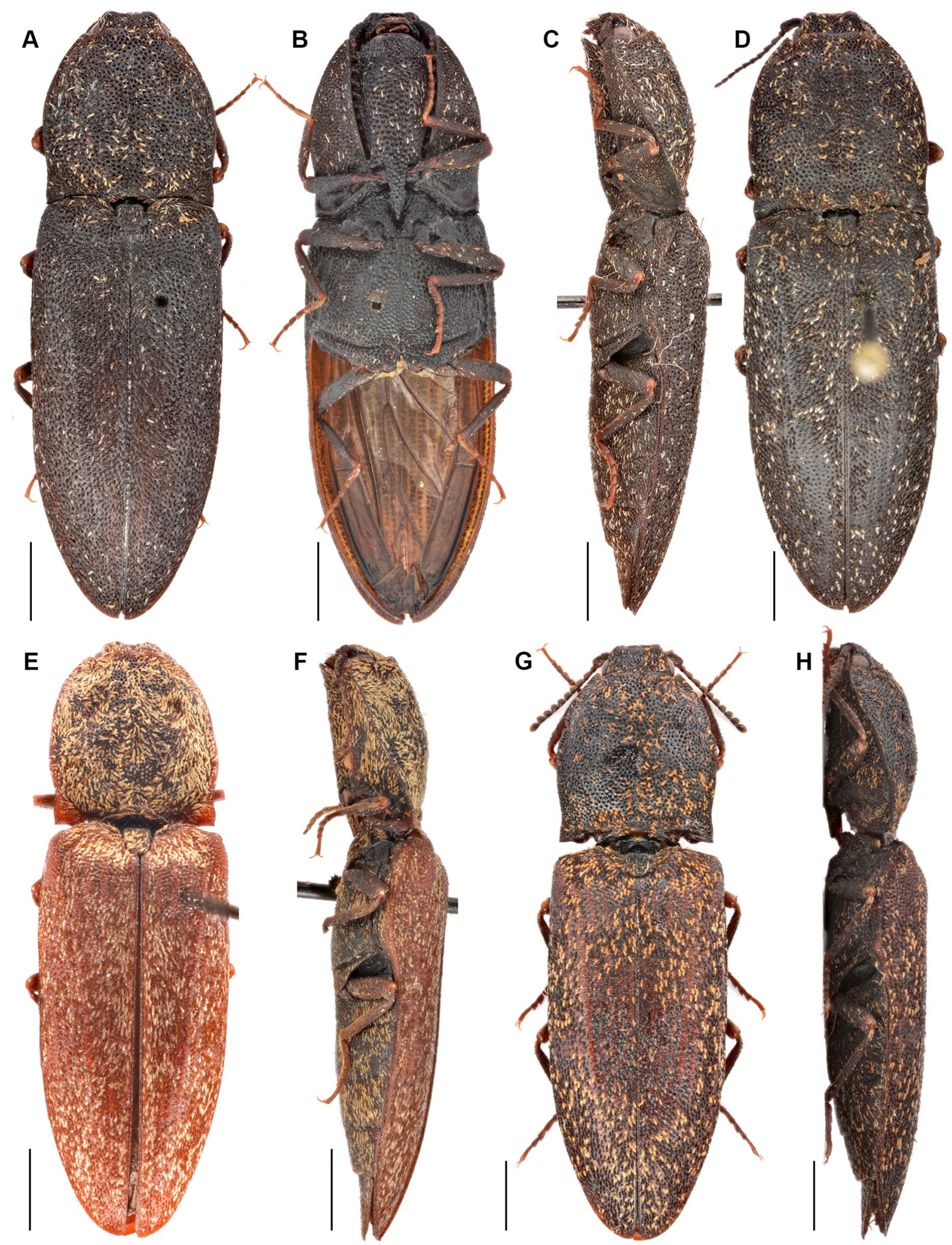

Fig. 1. Habitus images of Lacon spp. A-C. L. mertliki sp. nov, holotype, $\hat{O}$, in dorsal, ventral and lateral view, respectively. D. L. mertliki sp. nov, paratype, 9 , dorsal view. E-F. L. lepidopterus (Panzer, 1801), Ô (lectotype of L. aurosquamosus (Jagemann, 1944)) in dorsal and lateral view, respectively. G-H. L. lepidopterus, $\odot$ from Turkey in dorsal and lateral view, respectively. Scale bars $=2.0 \mathrm{~mm}$. 

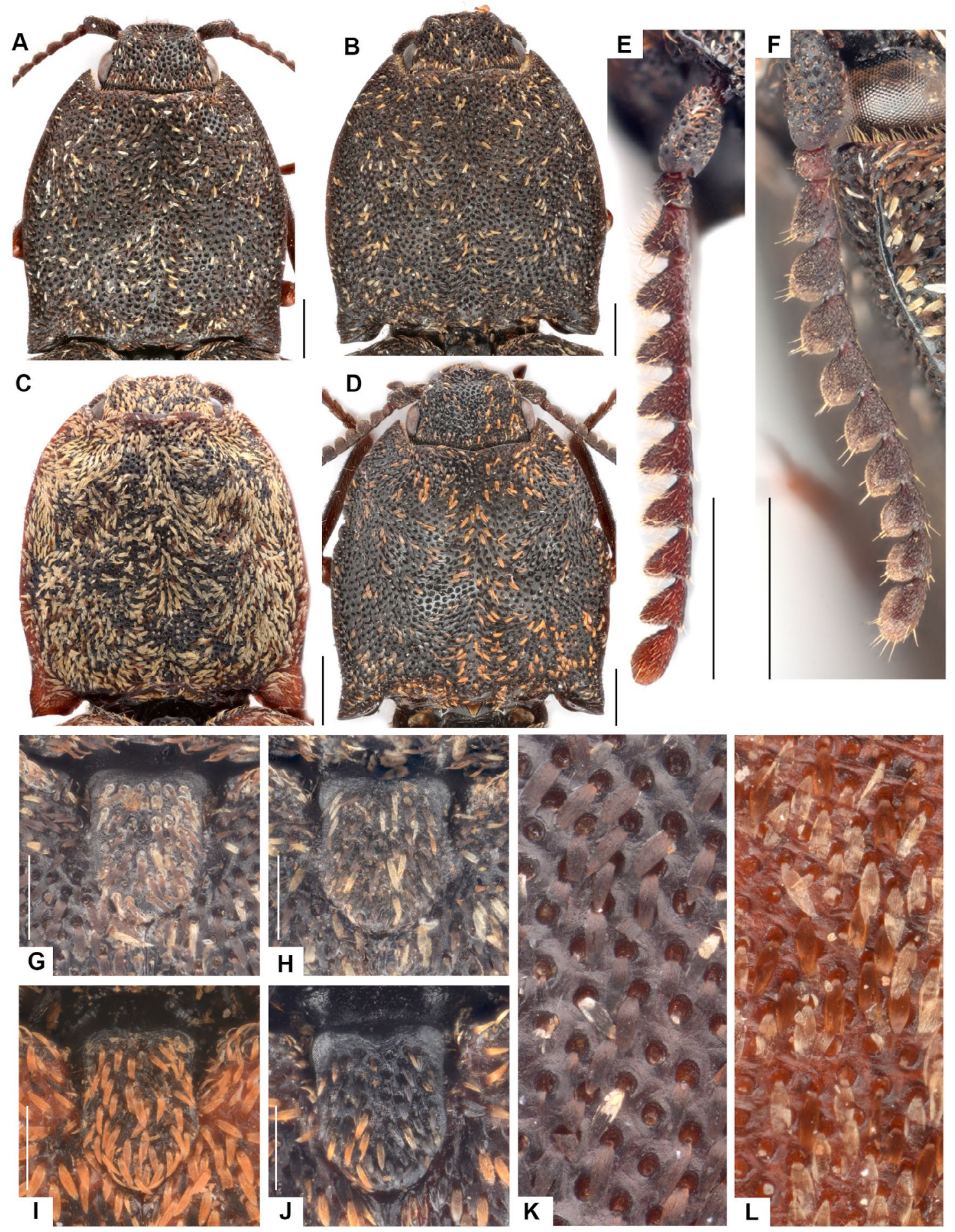

Fig. 2. Details of pronotum, antenna, scutellar shield and elytral surface of Lacon spp. A-D. Pronotum, dorsal view. A. L. mertliki sp. nov., holotype, ô. B. L. mertliki sp. nov., paratype, O. C. L. lepidopterus (Panzer, 1801), ठิ (lectotype of L. aurosquamosus (Jagemann, 1944)). D. L. lepidopterus, $\widehat{\partial}$ from Turkey. E-F. Antenna of $L$. mertliki sp. nov. E. Holotype, $\partial^{\lambda}$. F. Paratype,, . G-J. Scutellar shield. G. L. mertliki

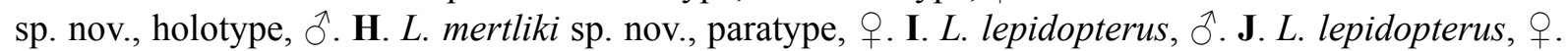

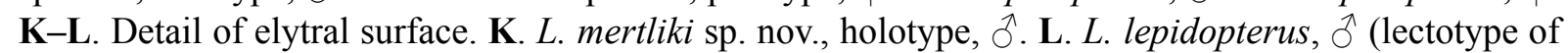
L. aurosquamosus). Scale bars: $\mathrm{A}-\mathrm{F}=1.0 \mathrm{~mm} ; \mathrm{G}-\mathrm{J}=0.5 \mathrm{~mm} ; \mathrm{K}-\mathrm{L}=$ not to scale. 
scale-like setae, with some additional white setae. Antennomeres II-XI covered with combination of blackish and yellowish hair-like; mouthparts covered with yellowish hair-like setae.

HeAd. Wider than long; frons with moderately deep median depression. Punctures coarse and dense, almost contiguous; surface between punctures smooth. Labrum transverse, convex, finely punctate, anteriorly rounded, with long, semi-erect hair-like pubescence. Mandible robust, relatively short, bidentate, basally with large punctures and long hair-like setae. Maxillary palp relatively short, apical palpomere securiform, more than 1.5 times as long as wide, apically obliquely widened, flattened and truncated. Antennae reaching near middle of pronotum, distinctly serrate from antennomere III. Scape long, robust, notably thicker than others; length ratio of antennomeres II-V as 1.0:2.0:1.8:1.8; antennomere II minute, short, slightly wider than long; antennomere III elongate; antennomeres IV-X about equal in shape, about as long as wide to slightly wider; last antennomere almost obovate. Antennae covered with moderately dense, decumbent, blackish hair-like setae, inner sides of antennomeres II-XI covered with additional erect yellowish hair-like setae.

Pronotum. Slightly wider than long (length $4.2 \mathrm{~mm}$; width $4.3 \mathrm{~mm}$ ), widest medially; sides widely rounded, slightly sinuate before posterior angles, from about half distinctly narrowed toward anterior margin; anterior angles short, sharp, reaching about half length of each eye; posterior angles rather short, flattened, very slightly divergent, almost rectangular. Pronotal disc with two pairs of tubercles in centre of disc laterally from median impression; anterior pair somewhat larger than posterior pair; with two deep distinct impressions before half, laterally from centre of disc, and two pairs of smaller and moderately deep impressions in the anterior and posterior third, respectively. Median depression on pronotal disc somewhat shortly divided by central part with tubercles; posterior part of depression very wide and deep; anterior part of depression shorter, rather narrow and shallow. Punctation of pronotum similar to punctation on head. Pronotosternal sutures deeply grooved almost over entire length. Prosternum elongate, about 2.5 times as long as wide, punctate similarly as pronotum; prosternal lobe short, with equally rounded anterior margin; surface rough, wrinkled. Hypomeron
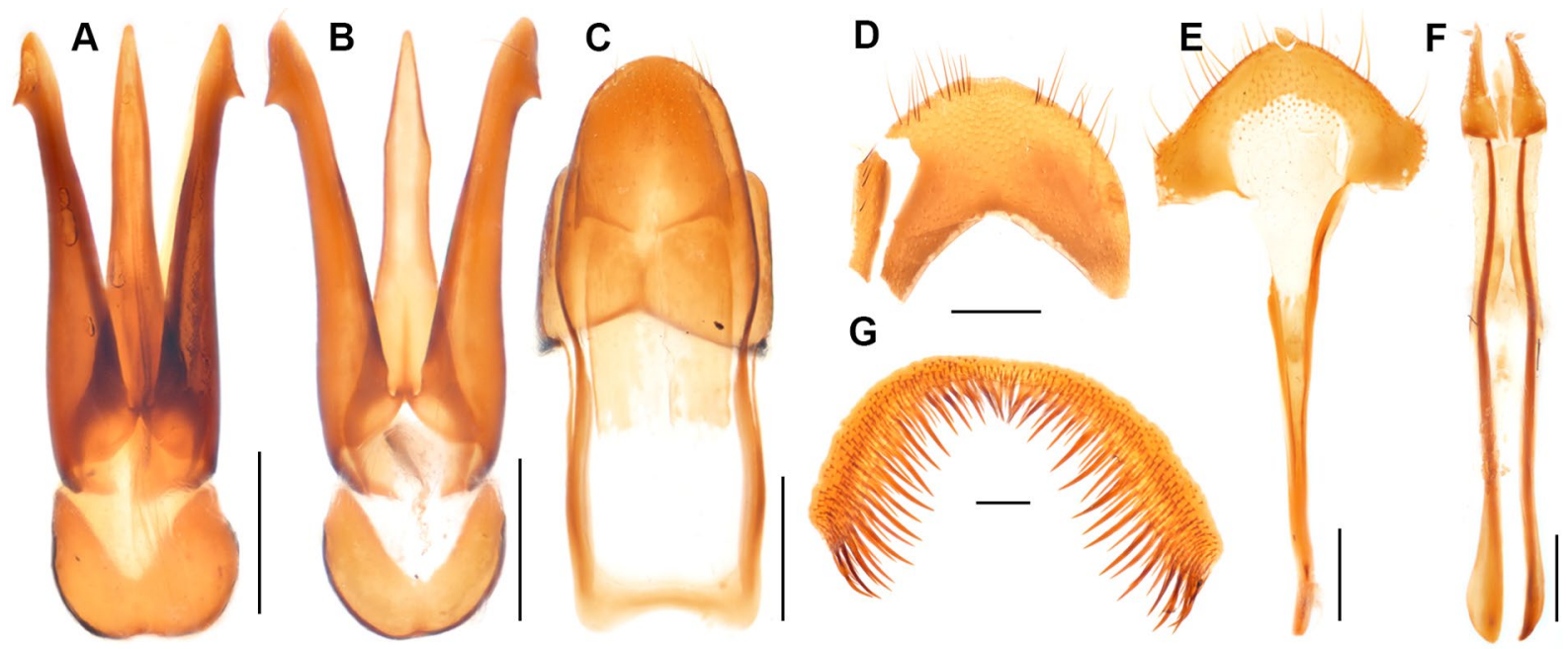

Fig. 3. Pregenital segments and genitalia of Lacon spp. A. L. lepidopterus (Panzer, 1801), § (lectotype of L. aurosquamosus (Jagemann, 1944)), aedeagus, dorsal view. B-C. L. mertliki sp. nov., holotype, . B. Aedeagus, dorsal view. C. Abdominal terminal segments. D-G. L. mertliki sp. nov., paratype, . D. Abdominal tergite VIII. E. Abdominal sternite VIII. F. Ovipositor. G. Large sclerite of bursa copulatrix. Scale bars $=0.5 \mathrm{~mm}$. 
with slightly denser and smaller punctures than punctures on prosternum; basally with smooth depression. Prosternal process slightly more than 3 times as long as diameter of procoxal cavity, with weak prominence near apex, narrowly rounded apically. Mesoventrite transverse; mesoventral cavity with well-defined walls; mesoventral process wide, apically truncate. Metaventrite robust, with large punctures; discrimen long, almost reaching anterior margin. Metacoxal plate narrowed at about half; wider part with posterior margin bisinuate. Scutellar shield about 1.35 times as long as wide, distinctly declined, flat, tongue-shaped, anterior margin weakly emarginate medially, sides subparallel, posteriorly weakly rounded, with large deep punctures, pubescence same as on elytra. Elytra slightly wider than pronotum, widest at about $1 / 3$, together about 2.2 times as long as wide (length $10.5 \mathrm{~mm}$; width $4.8 \mathrm{~mm}$ ), about 2.5 times as long as pronotum; subparallel-sided from humeri to posterior $1 / 3$, then slightly tapering to apex. Disc of elytra slightly convex near humeri, abruptly declined near scutellar shield, almost flattened after humeri, without striae but with elongate longitudinal keel running from humeri to about $2 / 3$ of elytral length, moderately densely covered with punctures subequal in size and shape, usually separated by about diameter of puncture. Epipleura complete, distinctly narrowed after metacoxae; its broader part covered with scale-like setae, narrower part covered with hair-like setae. Hind wings completely developed, reaching apex of elytra. Leg moderately long; tarsomere I slightly longer than combined lengths of tarsomeres II and III, but shorter than combined lengths of tarsomeres II-IV; tarsomeres II-IV longer than wide but relatively short, each one slightly shorter than preceding one; apical tarsomere longest, slender; pretarsal claws simple, slightly curved, each basally with long seta.

АвDomen. Ventrites moderately densely covered with small punctures; punctures larger and denser on ventrite 1 and on sides of each ventrite; apical ventrite rounded apically. Tergite IX transverse, wider than long, medially gradually emarginate. Tergite X slightly longer than wide, apically gradually rounded, finely punctate and covered with sparse setae. Sternite IX elongate, less than three times as long as wide, basally somewhat truncate, sides slightly constricted medially, apically equally rounded, covered with short setae, mainly at apex. Aedeagus elongate, about 3.2 times as long as wide. Median lobe elongate, slightly shorter than parameres, with short, robust basal struts, narrowed toward apex, apically narrowly rounded. Paramere elongate, gradually slightly narrowed toward apical lobe; apical lobe robust, elongate, rounded apically, with outer margin slightly emarginate, with short, stout, distinct lateral subapical hook. Phallobase relatively small, short, wider than long, U-shaped.

Female (Figs 1D, 2B, F, H, 3D-G)

Similar in body size and shape to male (body $15.5-17.5 \mathrm{~mm}$ long; $4.6-5.5 \mathrm{~mm}$ wide); slightly more robust than in male. Antenna slightly shorter, serrated antennomeres of different shape than in male, with serrations much wider and more distinctly widely rounded; erect setae on inner sides of antennomeres less numerous. Pronotal tubercles and impressions more developed; posterior angles slightly more divergent. Scutellar shield relatively wider, 1.15-1.20 times longer than wide. Tergite VIII subtriangular, wider than long, covered with fine punctures, apico-laterally with several short setae. Sternite VIII widely triangular, apically rounded, medially less sclerotized, sparsely covered with fine punctures and short setae; spiculum ventrale about 2.75 times sternite length. Ovipositor relatively long; paraprocts about 4.5 times as long as gonocoxites; styli present, short, subapically attached to gonocoxites. Bursa copulatrix membranous, sac-like, with large sclerite covered with short spinules and long spines, narrowed medially; distal small sclerite slender, transverse.

\section{Distribution}

Iran (Gilan, Golestan, Mazandaran). This species is probably distributed across the whole Hyrcanian forest belt. 


\section{Collecting circumstances}

Fresh material was collected in floodplain forests of the Golestan National Park and in montane primeval beech forests in the Mazandaran and Gilan provinces (Fig. 5A). Lacon mertliki sp. nov. was found in large logs of brown rotten wood (Fig. 5B) of Quercus castaneifolia C.A.Mey. and Alnus subcordata C.A.Mey., along with other beetle species like Clinidium marginicolle Reitter, 1889, Omoglymmius germari (Ganglbauer, 1891) (both Rhysodidae), Prostomis elburica Fleischer, 1919 (Prostomidae), Aesalus ulanowskyi Ganglbauer, 1887 (Lucanidae), Ampedus elegantulus (Schönherr, 1817) (Elateridae), and Uloma culinaris (Linnaeus, 1758) (Tenebrionidae) (J. Müller, pers. com.).

\section{Taxonomic remarks on $L$. unicolor and $L$. nadaii}

Lacon unicolor was described from Iran (Candèze 1874) and later reported from Turkey (Mertlik \& Platia 2008). Lacon nadaii was described from Iran and compared to L. unicolor due to their similar habitus and size (Platia \& Németh 2011). Lacon nadaii was distinguished from the latter species by "the black piceous colour, shagreened dorsal surface giving a dull appearance and shorter third antennomere" (Platia \& Németh 2011: 67). Mertlik \& Németh (2014) reviewed distribution of both species and found out that L. unicolor occurs only in Iran and L. nadaii in Turkey, Iraq and Iran. However, they also reported two intermediate specimens (both in the coloration and the length of antennomere III) from Turkey and Iraq. Prosvirov (2017) recorded L. unicolor from Iraq and found out that the external morphological characters of this species vary greatly but the shape of aedeagus is more or less uniform among the different populations. We examined the name-bearing types of both $L$. unicolor and L. nadaii as well as a long series of specimens from Iran, Iraq and Turkey from the MNHN, HNHM, NHMW, PCRK and PCJM collections (Fig. 4E-G), and we can confirm the findings of Prosvirov (2017). What is more, we found out that the differences in coloration and antennal morphology between L. unicolor and L. nadaii cannot be used for a reliable identification of these species and that there is a gradual intraspecific variability in these characters. Therefore, we propose that Lacon nadaii Platia \& Németh, 2011 is a junior subjective synonym of Lacon unicolor (Candèze, 1874).

\section{An identification key to the Lacon species from Iran}

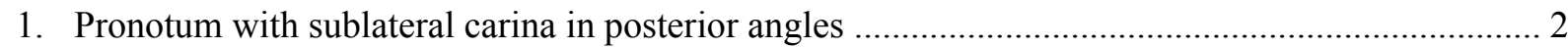

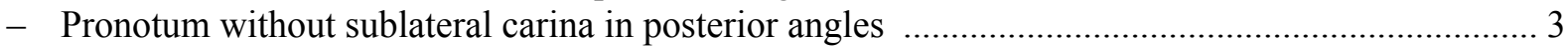

2. Pronotum more convex, with equally rounded sides; pronotal sublateral carina close to lateral carina; oblique keel on each elytron near scutellar shield distinct (Fig. 4C); parameral apical lobe short, equally rounded .. modestus (Boisduval, 1835)

- Pronotum less convex, more elongate, with widely rounded sides; pronotal sublateral carina distinctly far from lateral carina; oblique keel on each elytron near scutellar shield obsolete (Fig. 4D); parameral apical lobe elongate, narrowly rounded

L. mekrani (Candèze, 1889)

3. Pronotum longer than wide when width measured along half

- Pronotum about as long as wide or wider when width measured along half .................................... 5

4. Body covered with wide scale-like setae; pronotal punctation dense; pronotal posterior angles short, less sharp; punctures rough, large, often contiguous (Fig. 4B)

L. punctatus (Herbst, 1779)

- Body covered with thick hair-like setae; pronotal posterior angles distinct, long, sharp; pronotal punctation less dense; punctures smaller, separated by about 0.5-1 times their diameter (Fig. 4EG) L. unicolor (Candèze, 1874) 

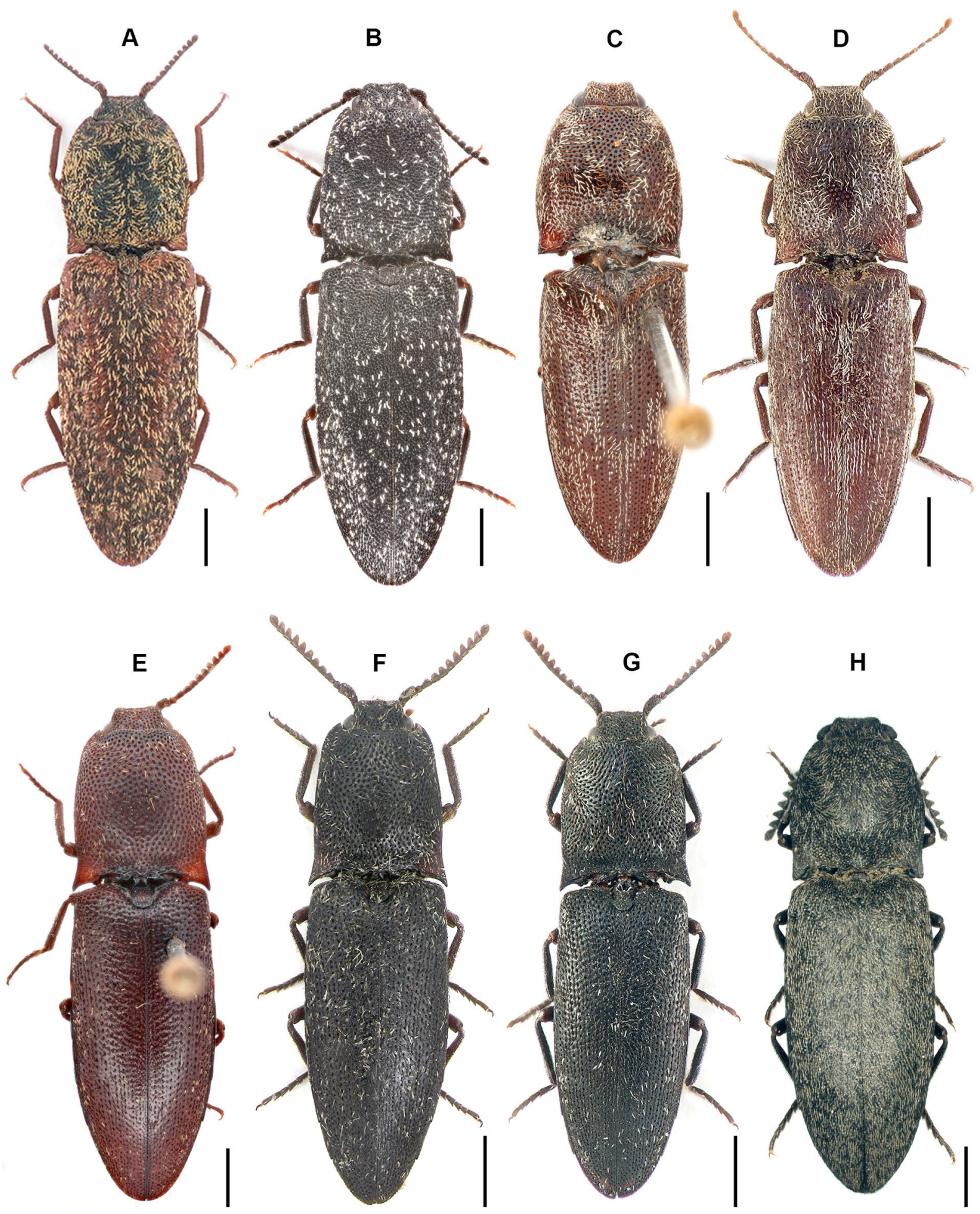

Fig. 4. Habitus images of Lacon spp., dorsal view. A. L. lepidopterus (Panzer, 1801), ․ B. L. punctatus (Herbst, 1779), ․ . C. L. modestus (Boisduval, 1835), lectotype, ․ D. L. mekrani (Candèze, 1889), ㅇ. E. L. unicolor (Candèze, 1874), lectotype, ․ . F. L. unicolor, Ô. G. L. nadaii Platia \& Németh, 2011, holotype, ô. H. L. funebris (Solsky, 1881), ठ․ Scale bars $=2.0 \mathrm{~mm}$. 
5. Body covered with hair-like setae; pronotal punctation sparse, punctures small (Fig. 4F)

L. funebris (Solsky, 1881)

- Body covered with scale-like setae; pronotal punctation dense, punctures rough, large 6

6. Body black; pubescence black and silver/yellowish with some white setae (Figs 1A-D, 2K); male pronotal posterior angles only slightly divergent (Fig. 2A); scutellar shield relatively wider, 1.35 times as long as wide in male, 1.15-1.20 in females (Fig. 2G-H); aedeagal paramere with apical lobe larger, robust (Fig. 3B); large sclerite of bursa copulatrix relatively wider and with shorter spines (Fig. 3G)

L. mertliki sp. nov.

- Body reddish brown to dark brown; pubescence usually uniformly golden (sometimes yellowish) and black (Figs 1E-H, 2L, 4A); male pronotal posterior angles more divergent (Fig. 2C); scutellar shield relatively narrower, $1.35-1.45$ times as long as wide in males, $1.25-1.30$ times in females (Fig. 2I-J); aedeagal paramere with apical lobe smaller, slender (Fig. 3A); large sclerite of bursa copulatrix relatively narrower and with longer spines (fig. 11 in Prosvirov 2016b)

L. lepidopterus (Panzer, 1801)

\section{Discussion}

The Hyrcanian forest ecoregion of Iran is about $800 \mathrm{~km}$ long narrow belt of deciduous forests on the northern slopes of the Alborz Mountains along the southern shore of the Caspian Sea. This region is one of the most important refugia and relicts of the pre-Quaternary broad-leaved deciduous forests in the Palearctic temperate zone (Sagheb Talebi et al. 2014; Tohidifar et al. 2016), and houses numerous beetles including Elateridae (Mardjanyan \& Barimani Varandi 2014; Platia \& Ghahari 2016; Jarzabek-Müller et al. 2017). Three Lacon species are reported from this region, i.e., L. lepidopterus, L. punctatus, and L. unicolor (Mertlik \& Németh 2014; Mardjanyan \& Barimani Varandi 2014; Platia \& Ghahari 2016) and here, we add a fourth one. Lacon mertliki sp. nov. is morphologically similar to L. lepidopterus and near species including L. quadrinodatus Lewis, 1894, L. altaicus (Candèze, 1857), and L. elegantissimus Prosvirov, 2016. This species group is characterized by the relatively robust body, dense scale-like body pubescence, short antennae in both sexes, typical pronotal sculpture consisting of tubercles and/or impressions, and the shape of male and female genitalia (Prosvirov 2016b). Lacon aurosquamosus (Jagemann, 1944), which was reported from Turkey and Iran (Cate 2007), was recently synonymized with L. lepidopterus (Mertlik \& Platia 2008), which is a rather variable species. The lectotype of L. aurosquamosus has lighter body and pubescence than the typical form of L. lepidopterus (Fig. 1E-F) but otherwise it shares with it all other characters including the shape of aedeagus (Fig. 3B here and fig. 7 in Prosvirov 2016b). Lacon mertliki sp. nov. differs from all the above mentioned species by the darker body and pubescence, the shape of pronotum, scutellar shield, apical lobe of aedeagal paramere, and a large sclerite of bursa copulatrix. We believe that despite the recent progress in the taxonomy of Lacon in the Middle East and Central Asia (e.g., Platia 2010; Mertlik \& Németh 2014; Prosvirov 2016b, 2017), more new species will be discovered in this region in near future. Forest Lacon species are worthy of study not only as part of the larger goal of cataloging the Elateridae fauna, but are very important for the nature protection initiatives since they can serve as focal and umbrella species for forest conservation (e.g., Nieto \& Alexander 2010; Eckelt et al. 2018).

\section{Acknowledgements}

We are grateful to A. Mantilleri (MNHN), O. Merkl (HNHM), M. Jäch, H. Schillhammer (NHMW), M. Barclay, M. Geiser (BMNH), S. Blank (SDEI), and J. Hájek (NMPC) for access to the collections in their care and/or loans of materiaL. Our special thanks go to A.S. Prosvirov (Moscow, Russia) for discussion on the Lacon morphology, to J. Mertlík (Opatovice nad Labem, Czech Republic) for loan of his specimens and various advice during our study, and to M. Barclay (BMNH) for English proofreading. Part of the material was collected by participants of the collaborative project "The diversity of dead- 
KUNDRATA R. et al., A new species of Lacon (Coleoptera: Agrypninae) from Iran
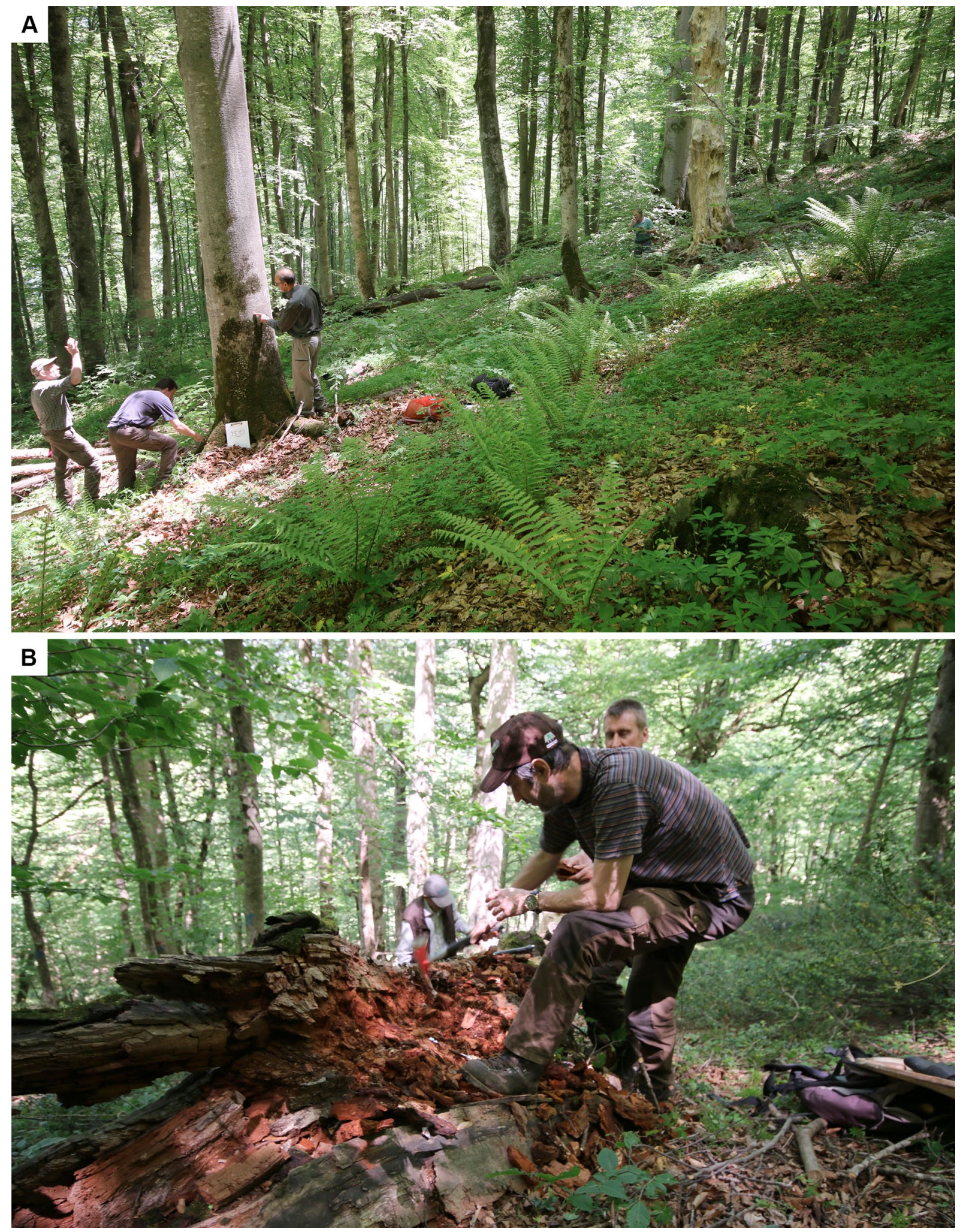

Fig. 5. Habitat of Lacon mertliki sp. nov. in Iran, Mazandaran province. A. Old-growth forest. B. Advanced brown rotten log. 
wood-related organisms in Hyrcanian forests" between the Research Institute of Forests and Rangelands (Iran), Bavarian Forest National Park (Germany), and University of Würzburg (Germany), with full consent of Iranian authorities. We thank F. Lange (Germany) and J. Müller (Germany) for providing specimens, and M.E. Farashiani (Iran), K. Sageb-Talebi (Iran), F. Kazerani (Iran) and H. Barimani Varandi (Iran) for organizing the project. This study was partially supported by the Tempus Public Foundation scholarships nrs. 287664 and 285948 (to RK and TN, respectively).

\section{References}

Candèze E.C.A. 1874. Révision de la Monographie des Élatérides. Fasc. 1. Mémoires de la Société royale des Sciences de Liége 2: 1-218. https://doi.org/10.5962/bhl.title.47120

Cate P. 2007. Elateridae Leach, 1818. In: Löbl I. \& Smetana A. (eds) Catalogue of Palaearctic Coleoptera. Vol. 4: Elateroidea - Derodontoidea - Bostrichoidea - Lymexyloidea-Cleroidea-Cucujoidea: 94-209. Apollo Books, Stenstrup.

Eckelt A., Müller J., Bense U., Brustel H. Bußler H., Chittaro Y., Cizek L., Adrienne A., Holzer E., Kadej M., Kahlen M., Köhler F., Möller G., Mühle H., Sanchez A., Schaffrath U., Schmidl J., Smolis A., Szallies A., Németh T., Wurst C., Thorn S., Haubo R., Christensen B. \& Seibold S. 2018. Primeval forest relict beetles of Central Europe: a set of 168 umbrella species for the protection of primeval forest remnants. Journal of Insect Conservation 22: 15-28. https://doi.org/10.1007/s10841-017-0028-6

Faucheux M.J. \& Kundrata R. 2017. Comparative antennal morphology of male Drilini with special reference to the sensilla (Coleoptera: Elateridae: Agrypninae). Zoologischer Anzeiger 266: 105-119. https://doi.org/10.1016/j.jcz.2016.11.002

Girard C. 2017. Catalogue commenté des Coléoptères Elateridae d'Afrique subsaharienne (Cardiophorinae exclus). Mémoires de la Société entomologique de France 10: 1-404.

Hayek C.M.F. von 1973. A reclassification of the subfamily Agrypninae (Coleoptera: Elateridae). Bulletin of the British Museum (Natural History). Entomology. Supplement 20: 1-309.

Hyslop J.A. 1921. Genotypes of the Elaterid beetles of the world. Proceedings of the United States National Museum 58: 621-673. https://doi.org/10.5479/si.00963801.2353.621

Jarzabek-Müller A., Morinière J., Barimani Varandi H. \& Müller J. 2017. Synaptus iranicus sp. nov., a second species of the genus Synaptus Eschscholtz, 1829 from Iran (Coleoptera: Elateridae) discovered by an integrative approach. Zootaxa 4232: 568-574. https://doi.org/10.11646/zootaxa.4232.4.6

Johnson P.J. 2002. Elateridae Leach 1815. In: Arnett R.H., Thomas M.C., Skelley P.E. \& Frank J.H. (eds) American Beetles, Vol. 2, Polyphaga: Scarabaeoidea through Curculionoidea: 160-173. CRC Press, Boca Raton, FL.

Kundrata R., Gunter N.L., Janosikova D. \& Bocak L. 2018. Molecular evidence for the subfamilial status of Tetralobinae (Coleoptera: Elateridae), with comments on parallel evolution of some phenotypic characters. Arthropod Systematics \& Phylogeny 76: 137-145.

Laporte F.L.N.C. 1838. Études entomologiques, ou descriptions d'insectes nouveaux et observations sur la synonymie. Revue Entomologique 4 [1836]: 5-60.

Mardjanyan M.A. \& Barimani Varandi H. 2014. New notes on fauna of click-beetles (Coleoptera, Elateridae) of Mazandaran province (Iran). Biological Journal of Armenia 3: 81-83.

Mertlik J. \& Németh T. 2014. Distributional notes on Lacon nadaii and L. unicolor (Coleoptera: Elateridae). Elateridarium 8: 61-66.

Mertlik J. \& Platia G. 2008. Catalogue of the family Cebrionidae, Elateridae, Lissomidae, Melasidae and Throscidae (Coleoptera) from Turkey. Elateridarium 2: 1-40. 
Nieto A. \& Alexander K.N.A. 2010. European Red List of Saproxylic Beetles. Publications Office of the European Union, Luxembourg.

Platia G. 2010. New species and chorological notes of click beetles from Palearctic Region, especially from the Middle East (Coleoptera, Elateridae). Boletín de la Sociedad Entomológica Aragonesa 46: 23-49.

Platia G. \& Ghahari H. 2016. An annotated checklist of click-beetles (Coleoptera, Elateridae) from Iran. Zootaxa 4137: 239-275. https://doi.org/10.11646/zootaxa.4137.2.6

Platia G. \& Németh T. 2011. On some Palaearctic click beetles deposited in the Hungarian Natural History Museum (Coleoptera: Elateridae). Annales Historico-Naturales Musei Nationalis Hungarici 103: 65-106.

Prosvirov A.S. 2016a. New and little-known species of the genus Lacon Laporte, 1838 (Coleoptera: Elateridae) of China. Zootaxa 4132: 373-382. https://doi.org/10.11646/zootaxa.4132.3.5

Prosvirov A.S. 2016b. New and little-known species of the genus Lacon Laporte, 1838 (Coleoptera: Elateridae) of Afghanistan and adjacent countries. Zootaxa 4168: 279-296.

https://doi.org/10.11646/zootaxa.4168.2.3

Prosvirov A.S. 2017. New data on the fauna and systematics of Palaearctic species of the click-beetle subfamily Agrypninae Candèze, 1857 (Coleoptera, Elateridae). Entomological Review 97: 1120-1136. https://doi.org/10.1134/S0013873817080127

Sagheb Talebi K., Sajedi T. \& Pourhashemi M. 2014. Forests of Iran. A treasure from the past, a hope for the future. Springer, Dordrecht/Heidelberg/New York/London.

Tohidifar M., Moser M., Zehzad B. \& Ghadirian T. 2016. Biodiversity of the Hyrcanian Forests: A synthesis report. UNDP/GEF/FRWO Caspian Hyrcanian Forest Project, Iran.

Manuscript received: 17 February 2019

Manuscript accepted: 27 May 2019

Published on: 5 July 2019

Topic editor: Gavin Broad

Section editor: Max Barclay

Desk editor: Pepe Fernández

Printed versions of all papers are also deposited in the libraries of the institutes that are members of the EJT consortium: Muséum national d'Histoire naturelle, Paris, France; Meise Botanic Garden, Belgium; Royal Museum for Central Africa, Tervuren, Belgium; Royal Belgian Institute of Natural Sciences, Brussels, Belgium; Natural History Museum of Denmark, Copenhagen, Denmark; Naturalis Biodiversity Center, Leiden, the Netherlands; Museo Nacional de Ciencias Naturales-CSIC, Madrid, Spain; Real Jardín Botánico de Madrid CSIC, Spain; Zoological Research Museum Alexander Koenig, Bonn, Germany; National Museum, Prague, Czech Republic. 